\title{
LLC inverter design procedure for induction heating with quantitative analysis of power transfer
}

\author{
Thuong Ngo-Phi ${ }^{1}{ }^{1},{ }^{,}$Nam Nguyen-Quang ${ }^{2}$
}

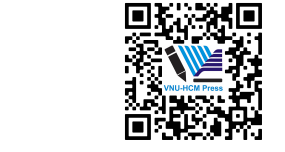

Use your smartphone to scan this QR code and download this article

${ }^{1}$ Electrical and Electronic Engineering, Cao Thang Technical College, Ho Chi Minh City, Vietnam

${ }^{2}$ Faculty of Electrical and Electronics Engineering, Ho Chi Minh City University of Technology, Ho Chi Minh City, Vietnam.

Correspondence

Thuong Ngo-Phi, Electrical and Electronic Engineering, Cao Thang Technical College, Ho Chi Minh City, Vietnam

Email:ngophithuongbk@gmail.com

History

- Received: 27-7-2020

- Accepted: 22-3-2021

- Published: 31-3-2021

DOI : 10.32508/stdjet.v4i1.751

\section{Check for updates}

\section{Copyright}

(c) VNU-HCM Press. This is an openaccess article distributed under the terms of the Creative Commons Attribution 4.0 International license.

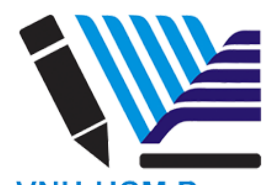

VNU-HCM Press

\begin{abstract}
Induction heating has been an advanced process for industrial quenching applications, aiming to increase the material's hardness to a desirable depth of penetration, with advantages such as high energy conversion efficiency, clean, safe and especially localized heating. In this process, an $\mathrm{L}$ coil with the right shape and size for the material to be heated will be normally used, and the matching between the coil size and the quenched material has a great effect on heating performance as well as the operation of the power converter, because it affects the airgap in the electromagnetic-thermal energy conversion system. Although induction heating has attracted a great deal of attention in recent years, design consideration of inductance in resonant circuits for specific requirements is still very limited. Specifically, there remains a need for a design process that uses the transferred power and workhead size as inputs, in practice. In this paper, the operating principle of an LLC resonant circuit for induction heating will be explained, from which a quantitative analysis of the transferred power to the workhead will be performed to help design the resonant circuit. An LLC circuit design procedure will be proposed, using the results from a quantitative analysis of the transferred power and taking into account the physical cons traints of the workhead. In addition, a simple technique for monitoring the soft-switching state of the power switches in a resonant inverter, based on monitoring the phase difference between the resonant capacitor voltage and the resonant circuit voltage, is also proposed. The feasibility of the proposed design process and phase tracking algorithm will be illustrated and verified through simulation and experiments on a $2 \mathrm{~kW}$, $100 \mathrm{kHz}$ LLC induction heating circuit for hardening hollow steel tubes up to $4 \mathrm{~cm}$ diameter.

Key words: Resonant inverters, Inductive power transmission, zero voltage switching
\end{abstract}

\section{INTRODUCTION}

Induction heating makes use of high frequency inverters, in which a resonant circuit is formed by a work-head and a capacitor in series ${ }^{1-4}$ or parallel configuration $^{5}$. The resonant inverter is responsible for supplying a large current in the work-head, with a heating load being represented as a resistor $\mathrm{R}$ in series or parallel with the coil. A resonant circuit is a popular solution to implement zero voltage switching (ZVS) or zero current switching (ZCS), in order to reduce switching losses ${ }^{6,7}$. Series resonant circuits may be used for all-metal induction heating with adaptive control ${ }^{8}$ or tundish induction heating with modular multilevel converter ${ }^{9}$. However, a combination of series resonant and parallel resonant (specifically, an LLC circuit) could provide better efficiency than a simple series resonant circuit ${ }^{6}$, especially in higher short-circuit capability and lower input current ${ }^{10}$. In ${ }^{6}$, the LLC was used in parallel-loaded form, in which the capacitor is in parallel with the primary coil of a coupling transformer. Another research proposed moving the $\mathrm{L}_{s}$ inductor to primary side of the transformer, resulting in lower current in that inductor ${ }^{10}$. However, only a calculation procedure for $\mathrm{L}_{S}$ and $\mathrm{C}$ was proposed, with the assumption that the value of $\mathrm{L}$ is already available. In addition, conditions for ZVS on power switches have not been identified. In this paper, a design procedure for LLC resonant circuits (in induction hardening) will be proposed, taking into account work-piece dimension and ZVS conditions. A demonstration system of $2 \mathrm{~kW}, 100 \mathrm{kHz}$ for surface hardening will be designed, built and tested. Simulations and experiments have been done to verify the proposed procedure.

\section{BASIC ANALYSIS METHOD OF THE LLC RESONANT CIRCUIT}

\section{LLC oscillation}

Figure 1 shows the proposed LLC resonant inverter, supplied by a three-phase bridge rectifier and an LC filter. The inverter is a $\mathrm{H}$-bridge, supplying the resonant circuit through a DC blocking capacitor $\left(\mathrm{C}_{b}\right)$ and a matching transformer ( $\mathrm{Tr}$ ). On the secondary side of the transformer is the LLC resonant circuit, includ-

Cite this article : Ngo-Phi T, Nguyen-Quang N. LLC inverter design procedure for induction heating with quantitative analysis of power transfer. Sci. Tech. Dev. J. - Engineering and Technology; 4(1):739-747. 


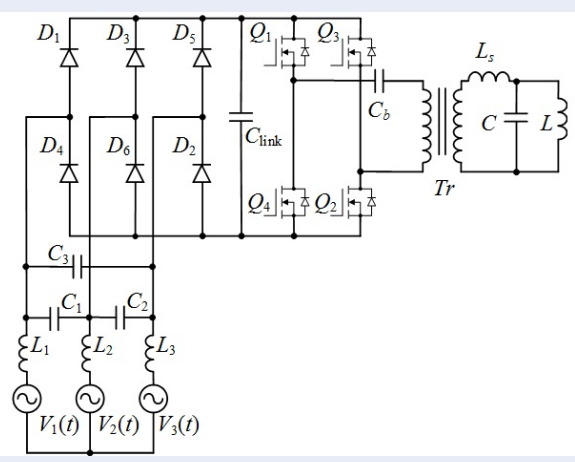

Figure 1: Power electronic for induction heating.

ing the series inductor $\mathrm{L}_{s}$, parallel capacitor $\mathrm{C}$, and the work-head L.

The LLC resonant circuit and matching transformer can be represented as in Figure 2, with $\mathrm{R}$ being reflected load.

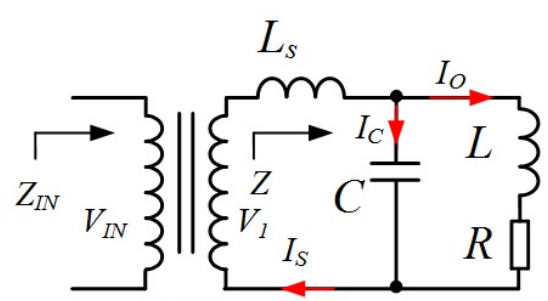

\section{$N: 1$}

Figure 2: LLC oscillation.

Impedance $Z(j \omega)$ looking at the LLC circuit can be expressed as

$$
\begin{aligned}
& Z(j \omega)= \\
& \frac{L \omega_{0}-L \omega_{0}\left(L_{n}+1\right)\left(\frac{\omega}{\omega_{0}}\right)^{2}+j L\left(L_{n}+1\right) \omega\left[1-\left(\frac{\omega}{\omega_{0}}\right)^{2}\right]}{Q\left[1-\left(\frac{\omega}{\omega_{P}}\right)^{2}\right]+j \frac{Q}{Q_{P} \omega_{P}} \omega}
\end{aligned}
$$

In which, $\mathrm{L}_{n}=\mathrm{L}_{s} / \mathrm{L}, \omega_{0}(2)$ and $\omega_{p}$ (3) are two resonant frequencies of the LLC circuit, and $\mathrm{Q}$ and $\mathrm{Q}_{p}$ are quality factors of the circuit at those frequencies, respectively.

$$
\begin{gathered}
\omega_{0}=\frac{1}{\sqrt{\frac{L L_{s}}{L+L_{S}} C}} \\
\omega_{P}=\frac{1}{\sqrt{L C}}
\end{gathered}
$$

In Figure 3a, magnitude and phase plots of impedance $\mathrm{Z}$ are presented, clearly show two resonant frequencies, $\mathrm{f}_{p}$ (for parallel resonance with highest magnitude) and $\mathrm{f}_{0}$ (for series resonance with lowest magnitude). Therefore, when designing this type of resonant circuit, the operating frequency should be slightly higher than $\mathrm{f}_{0}$, so that the circuit is close to resonant condition with an inductive impedance, supporting zero voltage switching. From phase plot, ZVS and ZCS operating zones can be identified (capacitive impedance for ZCS and inductive impedance for ZVS). Furthermore, at series resonance $\left(f_{0}\right)$ the impedance is inductive rather than resistive as in the second-order series resonant circuit. By substituting (2) and (3) into (1), one can prove that the impedance will possess a positive phase $\varphi 0$ at series resonance, as given in (5).

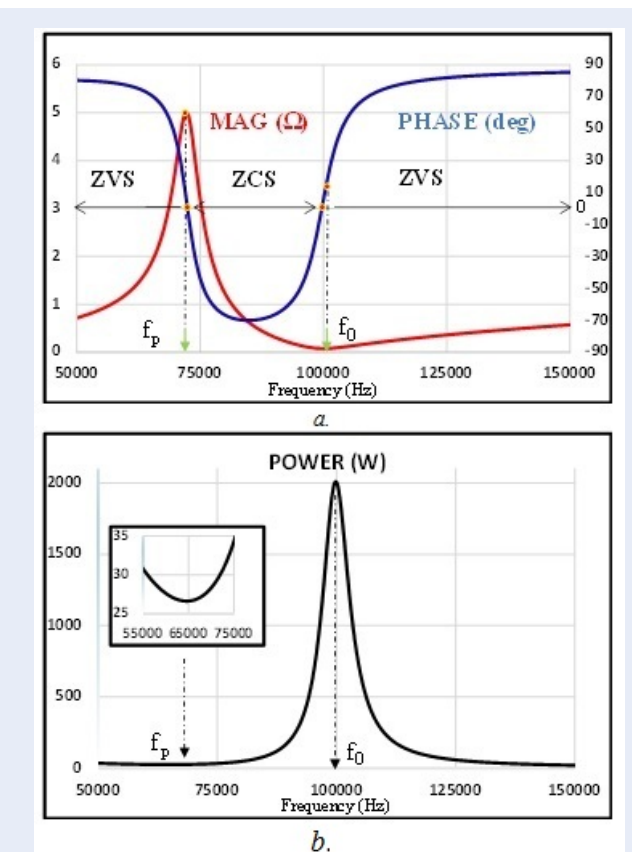

Figure 3: Steady - state behavior of the LLC oscillator.

$$
\begin{gathered}
Z\left(j \omega_{0}\right)=L \omega_{0}\left(\frac{L_{n}^{2}}{Q-j\left(L_{n}+1\right)}\right) \\
\varphi_{0}=\arg \left\{Z\left(j \omega_{0}\right)\right\}=\arctan \left(\frac{L_{n}+1}{Q}\right)
\end{gathered}
$$

From the magnitude plot, it can be seen that maximum power transfer occurs at resonance, and can be determined with the fundamental voltage $\mathrm{v}_{1}$, as given 
in (6).

$$
\begin{aligned}
P_{\max } & =v_{1}^{2} \operatorname{Re}\left\{\frac{1}{Z *\left(j \omega_{0}\right)}\right\} \\
& =\frac{v_{i n}^{2}}{L_{n}^{2} N^{2} R}\left[1+\left(\frac{L_{n}+1}{Q}\right)^{2}\right]
\end{aligned}
$$

According to (6), the maximum power depends on the applied voltage $\mathrm{v} 1$, inductance ratio Ln, quality factor $\mathrm{Q}$, and reflected load R. Furthermore, the ratio $\left(\mathrm{L}_{n}+1\right) / \mathrm{Q}$ should be much smaller than unity, corresponding to small $\varphi_{0}$, for reduced circulating current in the circuit. Therefore, the maximum power can be considered to depend on the applied voltage $\mathrm{v}_{1}$, inductance ratio $\mathrm{L}_{n}$, number of turns $\mathrm{N}$, and reflected load R. A typical power vs frequency curve is shown in Figure $3 \mathrm{~b}$, in which maximum power occurs at series resonance $\left(f_{0}\right)$ with a steep change around the peak, leading to a wide power range for a small frequency change.

\section{ZVS conditions}

Monitoring ZVS condition is crucial for a safe operation of this type of circuit. Therefore, a simple and effective monitoring method has been proposed, as described below.

Voltage on capacitor C in the LLC circuit can be determined as:

$$
\begin{aligned}
v_{c}(j \omega) & =\frac{Z_{L C R}(j \omega)}{Z(j \omega)} v_{1} \\
= & \frac{Z(j \omega)-j L_{s} \omega}{Z(j \omega)} v_{1}
\end{aligned}
$$

Where $\mathrm{Z}_{L C R}(\mathrm{j} \omega)$ is the equivalent impedance of two parallel branches, where $\mathrm{L}$ and $\mathrm{R}$ are in series in one branch, and $\mathrm{C}$ forms the other branch. From (4) and $(7)$, capacitor voltage at series resonance $\left(f_{0}\right)$ can be expressed as:

$$
v_{c}\left(j \omega_{0}\right)=\frac{-1-j Q}{\beta} v_{1}
$$

From (8), phase difference $\triangle \varphi$ between $\mathrm{v}_{c}$ and $\mathrm{v}_{1}$ can be calculated, as given in (9)

$$
\triangle \varphi=a c \tan (-Q)
$$

As mentioned above, for a small $\varphi_{0}$, quality factor $\mathrm{Q}$ should be large, normally larger than 6 in LLC circuits $^{11}$. Therefore, at resonance, capacitor voltage $\mathrm{v}_{c}$ will be nearly $90^{\circ}$ lagging with respect to input voltage $\mathrm{v}_{1}$. For ZVS operation on power switches, the operating frequency should be higher than resonant frequency $f_{0}$, and the closer to this resonant frequency the more power can be transferred. However, during the heating process, passive components may change their inductances and capacitances, leading to a change of resonant frequency. Then the phase difference $\mathrm{D} j$ calculated in (9) may be used to monitor resonant frequency, and circuit condition and maintain maximum power transfer.

\section{INDUCTION HEATING COIL INDUCTANCE}

In design procedures, inductance value of the workhead is normally given. However, the shape of workhead depends on the work-piece, so inductance value may be different among shapes. For radio-frequency (RF) induction heating, the work-head is usually an air-core solenoid, made by a copper tube to ease the cooling process and account for skin effect, as illustrated in Figure 4.

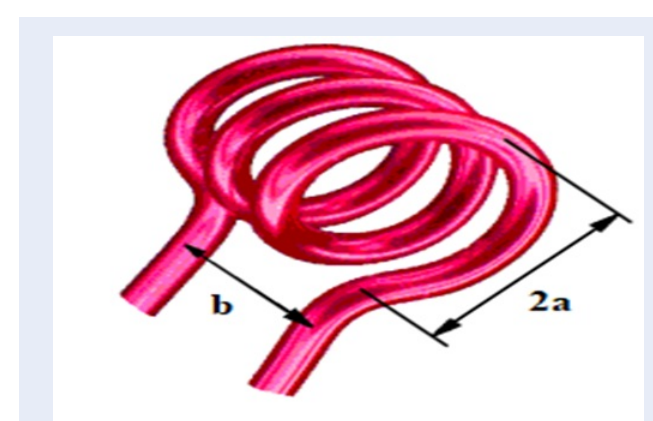

Figure 4: Induction coil as single layer coil.

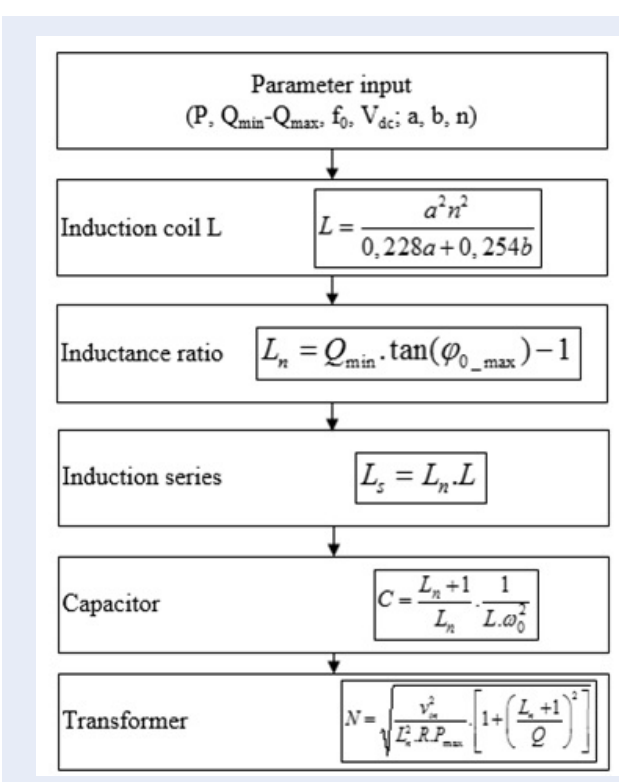

Figure 5: LLC inverter design procedure. 
Work-piece should be put inside the solenoid or close to solenoid.

An experimental formula ${ }^{12}$ can be used to calculate the inductance of the single layer solenoid:

$$
L=\frac{a^{2} n^{2}}{0.228 a+0.254 b} \mu H
$$

Where $a$ is the diameter of the solenoid, $b$ is the length, and $\mathrm{n}$ is the number of turns. These parameters depend on the work-piece shape and area to be heated up.

\section{LLC INVERTER DESIGN PROCEDURE}

A design procedure for LLC inverter has been proposed, as presented by the flow chart in Figure 5. Input parameters for designing the RF induction heater include: Desired dimension of the work-head (parameters $\mathrm{a}, \mathrm{b}$, and $\mathrm{n}$ ), heating power $\mathrm{P}$ (depending on heating temperature and time), DC link voltage, operating frequency $f_{0}$ (depending on skin depth), and variation range of the quality factor of the work-head and work-piece $\left(\left[\mathrm{Q}_{\min }, \mathrm{Q}_{\max }\right)\right]$. Below is a demonstration for the proposed design procedure with the following parameters: $\mathrm{a}=2.5 \mathrm{~cm}, \mathrm{~b}=12 \mathrm{~cm}, \mathrm{n}=11$ turns, $\mathrm{P}=2 \mathrm{~kW}, \mathrm{f}_{0}=100 \mathrm{kHz}, \mathrm{Q}_{\min }=6, \mathrm{Q}_{\max }=10$, and $\mathrm{V}_{d c}=500 \mathrm{~V}$.

Step 1: Calculation of work-head inductance $\mathrm{L}$

By applying (10), work-head inductance can be determined as:

$L=\frac{0.025^{2} \times 11^{2}}{0.228 \times 0.025+0.254 \times 0.12}=2.09 \mu \mathrm{H}$

$\mathrm{L}$ in (11) will be round up to $\mathrm{L}=2.1 \mu \mathrm{H}$.

Step 2: Calculation of $\mathrm{L}_{n}$ and $\mathrm{L}_{s}$ :

From (5), ratio $\mathrm{L}_{n}$ can be calculated from quality factor $\mathrm{Q}$ and switching angle $\varphi_{0}$. For a given $\mathrm{L}_{n}$, switching angle will be large for small values for $\mathrm{Q}$. Therefore, minimum quality factor $\mathrm{Q}_{\text {min }}$ will be used for this calculation. On the other hand, switching angle in LLC resonant circuits should be smaller than $20^{O} 11$, hence:

$$
L_{n}=6 \times \tan \left(20^{\circ}\right)-1=1.18
$$

From this ratio and the inductance value calculated in step 1, series inductance $\mathrm{L}_{s}$ can be determined:

$$
L_{s}=1.18 \times 2.1 \approx 2.4 \mu H
$$

Step 3: Calculation of $\mathrm{N}$

Fundamental component of the voltage applied to primary side of the transformer:

$$
v_{i n}=\frac{4 V_{d c}}{\pi \sqrt{2}}=\frac{4 \times 500}{\pi \sqrt{2}}=450 V_{R M S}
$$

Transformer's turns ratio should be selected so that a high current can be supplied from the secondary side of the transformer, in order not to create overvoltage on the capacitor C. From (6), a variation range for turns ratio $\left(\mathrm{N}_{\min }\right.$ to $\left.\mathrm{N}_{\max }\right)$ can be determined, corresponding to the range of quality factor $\left(\mathrm{Q}_{\max }\right.$ to $\left.\mathrm{Q}_{\min }\right)$, to achieve the rated power $\mathrm{P}_{\max }$ :

$$
N=\sqrt{\frac{v_{\text {in }}^{2}}{L_{i n}^{2} R P_{\max }}\left[1+\left(\frac{L_{n}+1}{Q}\right)^{2}\right]}
$$

For the demonstration system, it has been found that $\mathrm{N}_{\text {max }}=24$ and $\mathrm{N}_{\min }=19.3$. Select $\mathrm{N}=20$.

Table. 1 summarizes all design parameters for the demonstration system.

\section{SIMULATION RESULTS AND DISCUSSION}

To verify the feasibility of the design, a SPICE simulation will be done with the system schematic as shown in Figure 6.

The circuit should have ZVS operation, which is evaluated by examining its switching waveforms (Figure 7) on MOSFETs, in the target frequency range. Considering both current waveform (top graph) and voltage waveform (bottom graph) of $\mathrm{Q}_{4}$ MOSFET, the anti-parallel diode conducts before the gate-source voltage reaches a threshold value, making drainsource voltage slightly negative. Therefore, the MOSFET will be turn on at zero voltage, i.e. zero voltage switching.

An advantage of the LLC circuit is the ability to draw a smaller input current (output current from the inverter) compared to work-head current, as shown in Figure 8. It can be seen that the work-head current is sinusoidal at around $100 \mathrm{kHz}$, with a magnitude about 1.14 times the magnitude of the secondary current $\mathrm{I}_{L S}$ (bottom waveforms group). In top waveforms group, the capacitor voltage is sinusoidal and almost $90^{\circ}$ lagging with respect to input voltage $\mathrm{V}_{i n}$. Therefore, the designed LLC circuit has fulfilled requirements for sinusoidal output current, and ZVS on input switches, allowing higher efficiency and better heating effect.

\section{EXPERIMENTAL RESULTS AND DISCUSSION}

A prototype has been built to verify the ZVS operation and status monitoring with phase difference (Figure 9). In Figure 9a, a $380 \mathrm{~V}$ three-phase voltage was supplied to the diode rectifier through an LC line filter, a DC link capacitor was used to reduce the voltage ripple of the rectifier output. A standard $\mathrm{H}$-bridge was 


\begin{tabular}{lll}
\hline \multicolumn{2}{l}{ Table 1: Design Parameters } & \\
\hline Symbol & Quantity & Value \\
$\mathrm{V}$ & Line - line Voltage & $380 \mathrm{~V}$ (RMS) \\
$\mathrm{P}$ & Power heating & $2 \mathrm{~kW}$ \\
$\mathrm{~L}$ & Inductance & $2.1 \mu \mathrm{H}$ \\
$\mathrm{Q}$ & Quality factor & $6: 10$ \\
$\mathrm{f}_{s}$ & Switching frequency & $80-120 \mathrm{kHz}$ \\
$\mathrm{f}_{0}$ & Resonant frequency & $100 \mathrm{kHz}$ \\
$\mathrm{Ls}$ & Series resonant inductance & $2.4 \mu \mathrm{H}$ \\
$\mathrm{C}$ & Resonant capacitance & $2.2 \mu \mathrm{F}$ \\
$\mathrm{N}$ & Transformer ratio & $20: 1$ \\
\hline
\end{tabular}

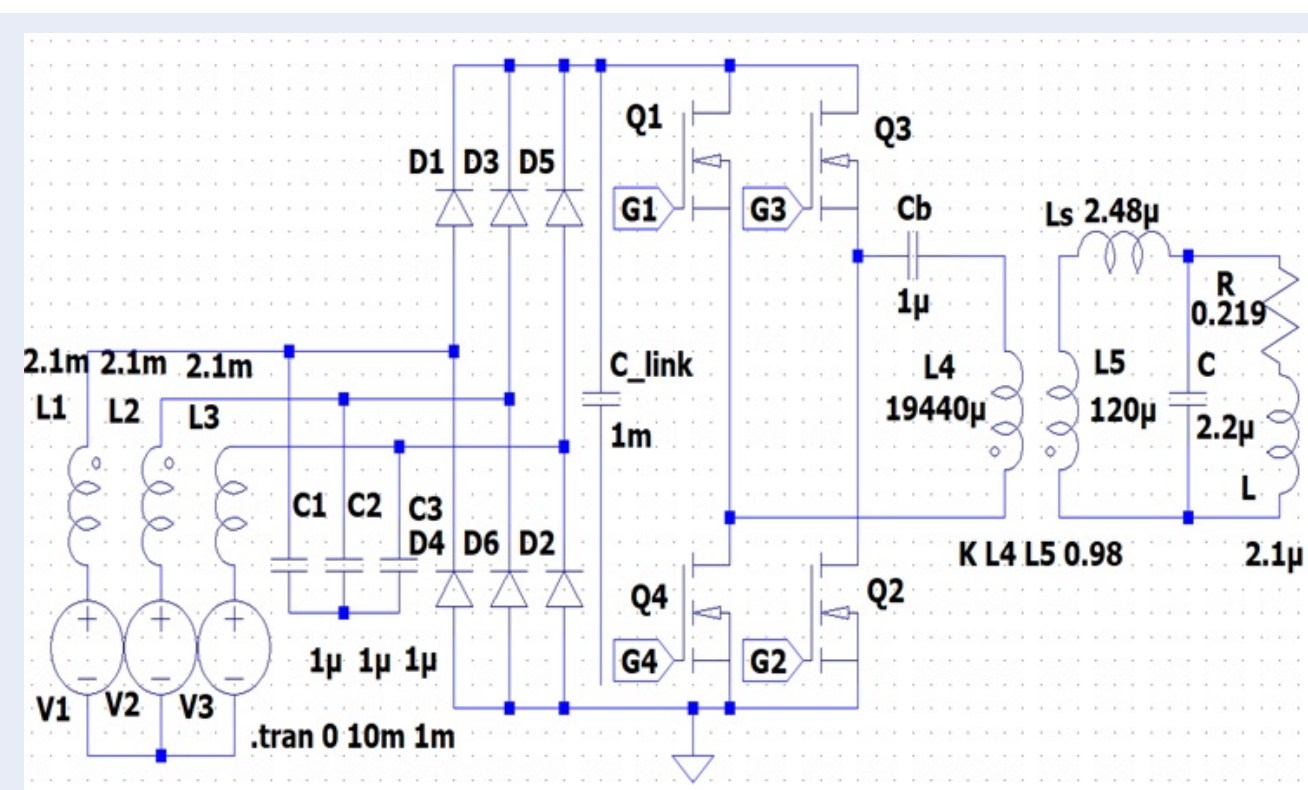

Figure 6: Simulation circuit in LTspice.

used to supply high frequency voltage to the matching transformer, energizing the LLC resonant circuit. The work-head was a solenoid made of copper tube and was water-cooled. A Tiva C Launchpad (EKTM4C123GXL) was used to provide gating signals at $100 \mathrm{kHz}$ to the power switches through gate drivers. The work-piece is a $4 \mathrm{~cm}$ diameter steel tube as shown in Figure $9 b$.

In Figure $10 \mathrm{a}$, the MOSFET current (bottom waveform) and the MOSFET voltage (top waveform) are in good agreement with corresponding waveform in simulation. Although gate signal was not shown, ZVS has been achieved in practice, according to the analysis presented in section 5. Due to internal impedance of power supply, impedance of the LC filter, and voltage drop on the rectifier, the available voltage at DC link will be reduced at high current value, leading to voltage dip as shown in Figure 10a.

In Figure 10b, filtered waveform of secondary voltage $\mathrm{v}_{1}$ and capacitor voltage $\mathrm{v}_{c}$ are shown, with nearly $90^{\circ}$ phase lagging on capacitor voltage with respect to the fundamental voltage, showing a near resonant working condition.

\section{CONCLUSION}

The paper has explained the operating principle of an LLC resonant circuit in induction heating applications, with a quantitative analysis of power transferred 


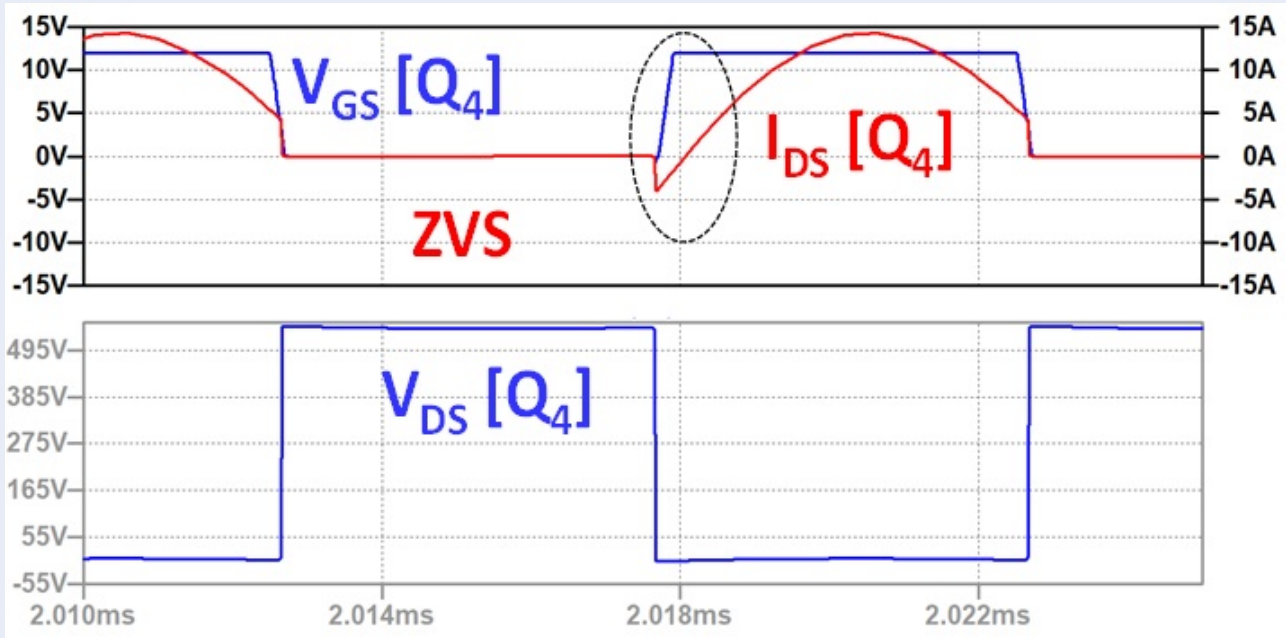

Figure 7: ZVS turn on in MOSFET (top graph: $\mathrm{I}_{D S}-$ Red, $\mathrm{V}_{G S}-$ Blue, bottom graph: $\mathrm{V}_{D S}-$ Blue)

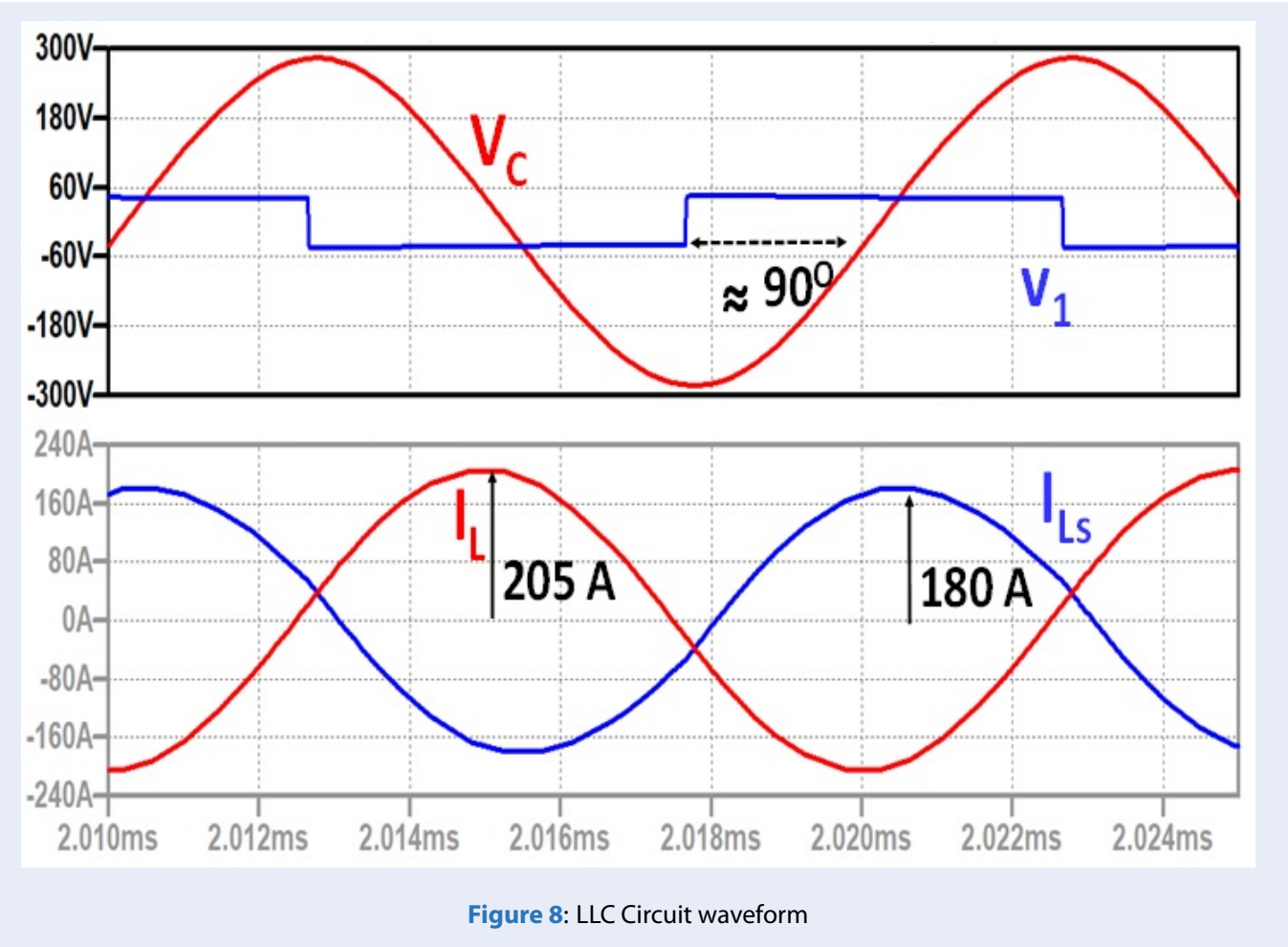




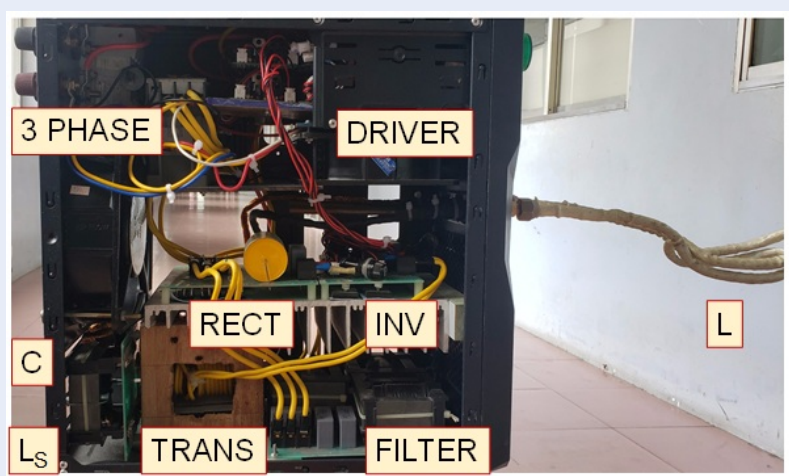

a. Experimental prototype

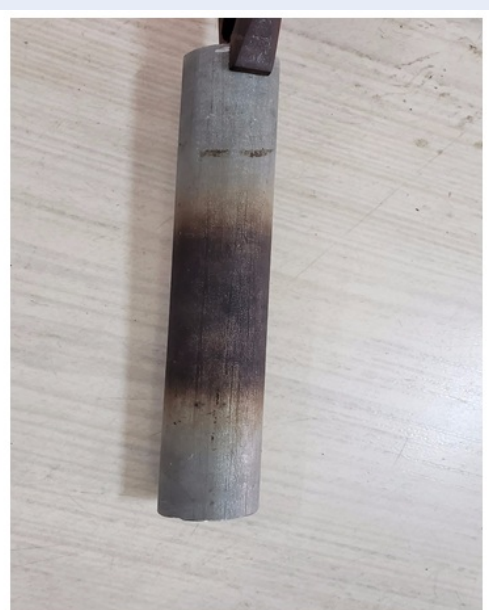

b. Work piece

Figure 9: Experimental Prototype

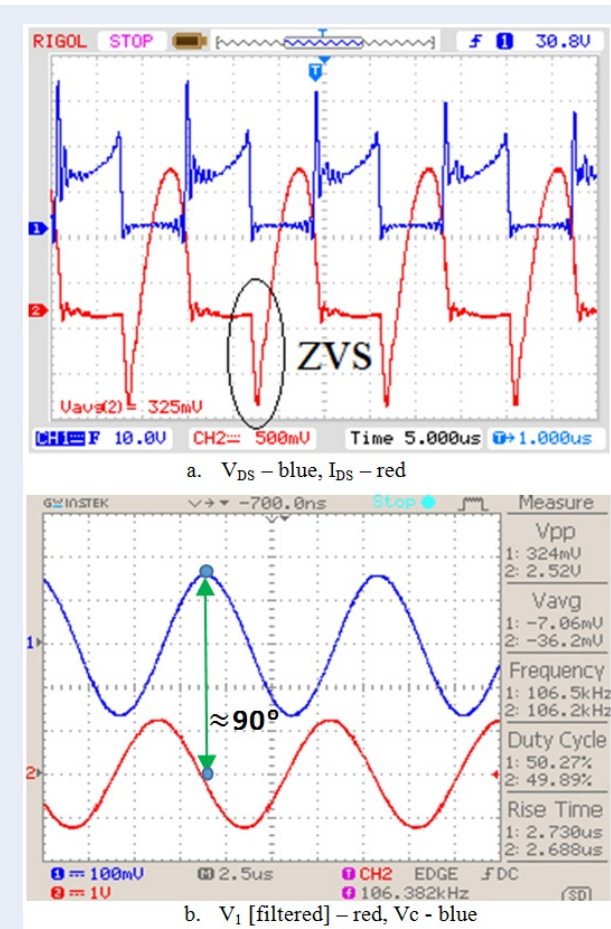

Figure 10: Experimental result.

to the work-head to help in design process. A design procedure for the LLC circuit has also been proposed, utilizing results from the quantitative power analysis and taking into account mechanical constraints on the work-head. The effectiveness of the proposed design procedure has been verified by simulations and experiments.

\section{LIST OF ABBREVIATIONS}

LLC: Inductor - inductor - capacitor ZVS: Zero voltage switching ZCS: Zero current switching RF: Radio - frequency

\section{CONFLICT OF INTEREST}

The authors confirm that they do not have any conflict of interest in completing this paper.

\section{AUTHORS' CONSTRIBUTION}

Thuong Ngo-Phi proposed the research idea, conducted simulations and experiments.

Nam Nguyen-Quang contributed to the technical background, hardware implementation, and proof reading.

\section{REFERENCES}

1. Park N, Lee D, Hyun D. A Power-Control Scheme with Constant Switching Frequency in Class-D Inverter for InductionHeating Jar Application. IEEE Transactions on Industrial Electronics. 2007;54(3):1252-1260. Available from: https://doi. org/10.1109/TIE.2007.892741.

2. Paul AK. ZVZCS SRI Guides Optimal Use of Copper and Core for Air-Cooled Nano crystalline Transformer for Induction Heating. IEEE Transactions on Industry Applications. 2020;56(2):970-978. Available from: https://doi.org/10.1109/ TIA.2020.2967329.

3. Gomes RCM, et al. Multiphase Resonant Inverter with Coupled Coils for AC-AC Induction Heating Application. IEEE Transactions on Industry Applications. 2020;56(1):551-560. Available from: https://doi.org/10.1109/TIA.2019.2955661.

4. Attab A, Zeroug $\mathrm{H}$, Hammouma C. Investigations into series resonant inverter power control parameters for an effective metal induction surface hardening," in IET Electric Power Applications. 2020;14(6):1097-1107. Available from: https: //doi.org/10.1049/iet-epa.2018.5740. 
5. Shenkman A, Axelrod B, Chudnovsky V. Assuring continuous input current using a smoothing reactor in a thyristor frequency converter for induction metal melting and heating applications," in IEEE Transactions on Industrial Electronics. 2001;48(6):1290-1292. Available from: https://doi.org/10. $1109 / 41.969415$.

6. Thuong NP, am Nguyen Quang. Improving Battery charging Efficiency with soft switching technique. Proc BRCORP, Ho Chi Minh City, Vietnam. 2016;p. 214-220.

7. Villa $J$, et al. Power estimation for dual half-bridge inverter with common resonant capacitor. IET Power Electronics. 2020;13(6):1267-1274. Available from: https://doi.org/10. 1049/iet-pel.2019.0904

8. Park $\mathrm{H}$, et al. Load adaptive modulation method for all-metal induction heating application. 2018 IEEE Applied Power Electronics Conference and Exposition (APEC), San Antonio, TX. 2018;p. 3486-3490. PMID: 29565128. Available from: https: //doi.org/10.1109/APEC.2018.8341606.
9. Yue $Y$, et al. Analysis and control of tundish induction heating power supply using modular multilevel converter. IET Generation, Transmission \& Distribution. 2018;12(14):3452-3460. Available from: https://doi.org/10.1049/iet-gtd.2017.1274.

10. Chudjuarjeen S, Sangswang A, Koompai C. An Improved \$LLC\$ Resonant Inverter for Induction-Heating Applications with Asymmetrical Control. IEEE Transactions on Industrial Electronics. 2011;58(7):2915-2925. Available from: https:// doi.org/10.1109/TIE.2010.2070779.

11. Espi-Huerta JM, Santamaria EJDG, et al. Design of the LLC Resonant Inverter for Induction Heating Based on Its Equivalent SRI. IEEE Transactions on Industrial Electronics. 2007;54(6):3178-3187. Available from: https://doi.org/10 1109/TIE.2007.905928.

12. Wheeler HA. Simple Inductance Formulas for Radio Coils. Proceedings of the Institute of Radio Engineers. 1928;16(10):1398-1400. Available from: https://doi.org/10. 1109/JRPROC.1928.221309. 


\title{
Quy trình thiết kế bộ nghịch lưu LLC với phân tích định lượng về công suất truyền
}

\author{
Ngô Phi Thường ${ }^{1, *}$, Nguyễn Quang Nam²
}

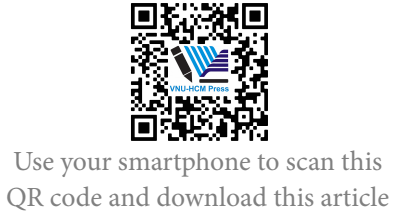

${ }^{1}$ Khoa Điện - Điện tử, Trường Cao đẳng Kỹ thuật Cao Thắng, Hồ Chí Minh, Việt Nam

${ }^{2}$ Khoa Điện - Điện tủ, Trường Đại học Bách khoa, ĐHQG-HCM, Việt Nam

\section{Liên hệ}

Ngô Phi Thường, Khoa Điện - Điên tử Trường Cao đẳng Kỹ thuật Cao Thắng, Hồ Chí Minh, Việt Nam

Email: ngophithuongbk@gmail.com

Lịch sử

- Ngày nhận: 27-7-2020

- Ngày chấp nhận: 22-3-2021

- Ngày đăng: 31-3-2021

DOI : 10.32508/stdjet.v4i1.751

\section{Check for updates}

\section{Bản quyền}

๑ ĐHQG Tp.HCM. Đây là bài báo công bố mở được phát hành theo các điều khoản của the Creative Commons Attribution 4.0 International license.

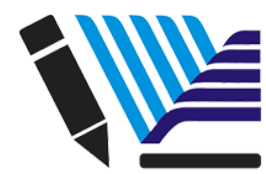

VNU-HCM Press

\section{TÓM TẮT}

Gia nhiệt bằng đốt nóng cảm ứng đã là một quy trình tiên tiến cho các ứng dụng tôi trong công nghiệp, nhằm tăng độ cứng của vật liệu đến một độ thấm sâu cho phép, với những ưu điểm nhu hiệu suất chuyển đổi năng lượng cao, sạch, an toàn và đặc biệt là khả năng làm nóng từng phần cho chi tiết cần tôi. Trong quá trình này, thông thường một cuộn dây L sẽ được sử dụng với hình dạng và kích thước phù hợp với vật liệu cần gia nhiệt, sự phù hợp giữa kích thước cuộn dây $L$ và vật liệu tôi có ảnh hưởng lớn đến hiệu suất đốt nóng cũng như hoạt động của bộ biến đổi công suất vì sẽ ảnh hưởng đến khoảng hở không khí của hệ thống chuyển đổi năng lượng điện-từ-nhiệt. Mặc dù đốt nóng cảm ứng đã thu hút mạnh mẽ sự quan tâm trong những năm gần đây, nhưng việc thiết kế điện cảm trong mạch cộng hưởng cho các yêu cầu cụ thể vẫn ít được xem xét. Cụ thể, vẫn cần có một quy trình thiết kế sử dụng công suất yêu cầu và kích thước của cuộn đốt làm đầu vào, trong thực tế. Trong bài báo này, nguyên lý hoạt động của một mạch cộng hưởng LLC dùng cho đốt nóng cảm ứng sẽ được giải thích, từ đó một phân tích định lượng về công suất truyền đến cuộn đốt sẽ được thực hiện để giúp thiết kế mạch cộng hưởng. Một quy trình thiết kế mạch LLC sẽ được đề xuất, sử dụng các kết quả từ phân tích định lượng về công suất và có xét đến các ràng buộc vật lý của cuộn đốt. Ngoài ra, một kỹ thuật đ̛ơn giản để giám sát trạng thái chuyển mạch mềm của các khóa công suất trong mạch nghịch lưu cộng hưởng, dựa trên việc theo dõi lệch pha giữa điện áp của tụ điện cộng hưởng và điện áp mạch cộng hưởng, cũng được để xuất. Tính khả thi của quy trình thiết kế và giải thuật theo dõi pha đề xuất sẽ được minh họa và kiểm chứng thông qua mô phỏng và một mạch thực nghiệm đốt nóng cảm ứng LLC 2 kW, 100 kHz cho ứng dụng tôi vật liêu thép rỗng ruột đường kính $4 \mathrm{~cm}$.

Từ khoá: Nghịch lưu cộng hưởng, Truyền năng lượng cảm ứng, Chuyển mạch với điện áp bằng không
Trích dẫn bài báo này: Thường N P, Nam N Q. Quy trình thiết kế bộ nghịch lưu LLC với phân tích định lượng về công suất truyền. Sci. Tech. Dev. J. - Eng. Tech.; 4(1):739-747. 